The family doctor and the hospital casualty officer are usually among those first consulted, and even though expert advice is available they have to decide whether a prima facie case exists for prophylactic treatment. Nevertheless, a decision to administer rabies vaccine is rather easier than it once was. The current vaccines, such as the human diploid cell system vaccine, ${ }^{4}$ are not only more effective but also more acceptable than their predecessors. They require fewer injections of smaller volumes, given less frequently, and with relatively few side effects. Furthermore, human (as opposed to animal) immune rabies globulin is now available, and while this may slow down the development of active immunity it does not prevent it, and in the meantime it gives immediate protection. What about local treatment of the bite ? Most patients seen in Britain will have had some form of treatment, but, if not, the usual advice is that a recent wound should be thoroughly cleansed and iodine or alcohol applied. ${ }^{5}$ If human immune rabies globulin is being used some should be infiltrated locally.

On the major decision about active and aggressive prophylaxis the buck stops with the doctor, but guidelines may be given. If a patient presents with a history of a physically effective exposure to the saliva of an animal, in a place other than one of the rabies-free areas of the world, and the animal has either been found at necropsy to be rabid or is untraced after ten days, there is a prima facie case for undertaking rabies prophylaxis. This is never to be undertaken lightly, but at least it can now be done with more peace of mind, and a greater expectation of success, than ever before.

${ }^{1}$ Gardner, S D, Health Trends, 1977, 9, 35.

2 Macdonald, J, Health Trends, 1977, 9, 33.

3 Turner, G S, Recent Advances in Clinical Virology, 1977, 1, 79.

4 Aoki, F Y, et al, Lancet, 1975, 1, 660.

5 Klenerman, L, Coid, C R, and Aoki, F Y, British Medical fournal, 1975, 3, 740 .

\section{Crossman diaries}

The latest of the Crossman diaries ${ }^{1}$ provides the first day-today account of the problems of steering the National Health Service as seen from the driver's seat. As such, this record of Richard Crossman's period in office as Secretary of State for Social Services from 1968 to 1970 is unique. A very idiosyncratic account, it bears in every sentence the imprint of his volatile personality and strong prejudices. Like all the best diaries, it is convincing precisely because it reveals its author's character rather than because it is an objective or accurate chronicle of what happened. Inevitably, the Crossman version of history will be challenged by other participants in the events he described; but, this said, the diaries do illuminate the problems faced by all Secretaries of State, whether Labour or Conservative, and the difficulties inherent in the present system of political control over the NHS.

Most conspicuously the diaries emphasise that the affairs of the NHS are only one among many competing preoccupations for the Secretary of State. Not only is he responsible too for social security-a subject which claimed much of Crossman's time at DHSS, since he was busy devising a new national superannuation scheme-but also he is deeply concerned with Cabinet and Parliamentary business. In addition, he is a party politician busy addressing meetings all over the country and attending conferences. So issues arising out of the affairs of the NHS, and even major policy decisions like the future organisation of the Service, have to be dealt with as and when time permits. The routine is breathless and punishing.
No doubt these problems could be ascribed to ministerial overload-too many issues chasing too little time-or to Crossman's disposition to meddle in everything, from incomes policy to economic strategy. Yet many of the difficulties seem to be inherent in the nature of the office. As a member of the Cabinet, the Secretary of State has a duty to concern himself in decisions which eventually will have implications for the NHS. He cannot put himself at a distance from the management of the economy-since quite clearly the financial problems of the NHS largely reflect the economic problems of the country. Moreover, it is essential for the Secretary of State to carry clout in Cabinet. Crossman, for example, had a running battle with the Chancellor of the Exchequer in defending (largely successfully, it seems) the NHS from threatened cuts in public expenditure. Rather than demanding that the Secretary of State should devote more time to the NHS, doctors might therefore be more sensible to settle for a strong minister of state responsible for all day-to-day decisions.

The Crossman diaries also underline just how much the policies of any Secretary of State are circumscribed by his Cabinet colleagues and the Civil Service machine. When preparing his reorganisation Green Paper Crossman was anxious to devise a more decentralised system with greater representation by the professions and local authorities. In the outcome, however, he seems to have been defeated by the Treasury, which successfully insisted that central finance must also mean central control, thus limiting the scope for decentralisation. Again, the Secretary of State is largely dependent for information on his civil servants and (even discounting Crossman's notorious unfairness) clearly standards varied rather widely at the DHSS. Indeed, Crossman drew much of his inspiration for new ideas from visits to individual hospitals and the experiments of pioneering doctors. His real criticisms are reserved not so much for the medical profession as for the administrative machine: "One of the things which strikes me about the hospital service is how bad they are at not disciplining and dismissing," he records in his diary; "a man could have had no training when he started in 1948 and be there 20 years later, mucking things up, but never be sacked because of the Whitley Council or some other objection."

Yet, despite his obvious commitment to improving the NHS and creating a more flexible service, Crossman ended up incurring the suspicion and hostility of the medical profession. Indeed, at the end of the diary we leave him feeling betrayed by the doctors at the time of the crisis over the Kindersley pay award in 1970-a feeling which was emphatically reciprocated. He was doing his best, he felt, by fighting on the doctors' behalf in Cabinet, yet they did not appreciate his efforts. This experience seems to underline a basic dilemma for all Secretaries of State. All office holders are in the unenviable position of being regarded as the agents of Government by the Health Service professions and as agents of the professions by their ministerial colleagues. They cannot hope to win so long as decisions about pay in the public sector are made a political issue and so long as the implications of any settlement for other occupations are considered to be more important than the intrinsic merits of any individual claim. Inevitably, they sooner or later lose credibility as champions of their own service. That is perhaps a lesson which the members of the Royal Commission on the NHS might ponder as they read the Crossman diaries-which, despite their full filing cabinet, ought to be obligatory homework for them, as for all those interested in the concerns of the NHS.

\footnotetext{
${ }^{1}$ Crossman, Richard, The Diaries of a Cabinet Minister, vol 3. London,
} Hamish Hamilton and Jonathan Cape, 1977. 